undigested by papain increased as the arterial tree was descended.

The results show the following important characteristics of the glycosaminoglycan pattern.

(a) Only slight alterations in the distributions are produced as a result of feeding a diet known to produce atherosclerosis in this species ${ }^{3}$. (b) The total glycosaminoglycan content is greater in the thoracic aorta than in the abdominal aorta. (c) The hyaluronic acid fraction (1) is present in greatest proportion in the thoracic section of the aorta. (d) The heparan sulphate fraction (2) comprises a much greater proportion of the glycosaminoglycans in the abdominal aorta than it does in the ascending and thoracic aorta segments. (e) The proportion of the chondroitin sulphate fraction (3) is relatively constant in all sections of the aorta. (f) The dermatan sulphate fraction $(4+5)$ is present in lowest proportion in the abdominal aorta.

Thus, the distribution of glycosaminoglycans in chicken aorta varies in the different sections of the tissue; the variation does not parallel that observed by other workers with human aortic tissue ${ }^{8}$; only slight alterations in the distributions are produced as a result of feeding a diet known to produce atherosclerosis in this species ${ }^{3,9}$.

Zusammenfassung. Es wird gezeigt, dass die Verteilung von Glukosaminoglykane in der Hühneraorta offenbar im Unterschied $\mathrm{zu}$ menschlichem Aortengewebe in $\mathrm{Ab}$ hängigkeit der topographischen Lage steht. Höchste Gesamtwerte für Glykosaminoglykan wurden in der Brustaorta, niedrigste in der abdominalen Aorta gefunden.

\section{Susan Farguhar and J. R. Dunstone}

Department of Physical Biochemistry, John Curtin School of Medical Research, Australian National University, Canberra (A ustralia), 18 October 1967.

8. Mantey and J. HAwksworth, Nature 206, 1152 (1965).

$\checkmark$ Acknowledgments: This investigation was supported, in part, by the National Heart Foundation of Australia. The technical assistance of Miss B. FIELDHousE is appreciated.

\title{
Detection of Fusaric Acid in the Mycelium and Conidia of Fusarium oxysporum $\mathrm{f}$. vasinfectum
}

Fusaric acid (FA) (5-n-butyl picolinic acid) is produced by a large number of Fusarium spp. and the toxin was so far not detected in the mycelium ${ }^{1}$. Recently we found ${ }^{2}$ that Fusarium oxysporum f. vasinfectum (Atk.) Snyder and Hansen produced the toxin in the cotton plants within $12 \mathrm{~h}$ of inoculation which suggested that the toxin was readily released by the pathogen. The detection of fusaric acid in the mycelium and conidia is reported in this note.

The fungus was grown in Czapek's medium for 10 days at room temperature $\left(28 \pm 2^{\circ} \mathrm{C}\right)$. The mycelium was removed, washed 3 times with distilled water and the excess moisture was removed by blotting. $50 \mathrm{~g}$ of the mycelium was continuously extracted in a Soxhlet apparatus for $14 \mathrm{~h}$ with ethyl acetate $(10 \mathrm{ml} / \mathrm{g})$. The ethyl acetate extract was divided into 2 aliquots: 1 aliquot (I) was evaporated to dryness and the residue was dissolved in $2 \mathrm{ml}$ methanol. The other aliquot (II) was also evaporated to dryness but the residue was dissolved in $25 \mathrm{ml}$ distilled water, acidified to $\mathrm{pH} 3.0$ with $2 \mathrm{~N}-\mathrm{HCl}$ and extracted with equal volumes of ether 3 times. The ether extract was evaporated and the residue was dissolved in $2 \mathrm{ml}$ methanol.

About $100 \mu$ of the fractions were spotted on Whatman No. 1 filter paper and developed descendingly in $n$-butanolacetic acid-water $(4: 1: 1)$. The papers were air dried and separately sprayed with bromo phenol blue (BPB); $1 \%$ $\mathrm{Cu} \mathrm{So} \mathrm{S}_{4}$ BPB and modified DRAGENDORFF's reagent ${ }^{3}$.

A spot corresponding to authentic FA (courtesy of Prof. Dr. H. KERN, Eidg. Technische Hochschule, Zurich, Switzerland) which matched in Rf value (0.87) and colour reactions was detected. Whereas aliquot II contained only FA, aliquot I contained 4 more copper chelating compounds (Rf $0.72,0.65,0.57,0.46$ ) in addition to $\mathrm{FA}$.

The toxicity of FA was bioassayed by aseptically applying the extract to filter paper discs of $1.1 \mathrm{~cm}$ diameter, air dried, placed on Bacillus subtilis seeded nutrient agar plates and incubated at room temperature for $12 \mathrm{~h}$. The area of inhibition measured by the method of SMALE and $\mathrm{KEIL}^{4}$ revealed that $100 \mu \mathrm{l}$ of the extract caused an in- hibition of $114 \mathrm{~mm}^{2}$ while at $300 \mu \mathrm{l}$, it was $267 \mathrm{~mm}^{2}$. The spot corresponding to known FA cut from paper chromatograms inhibited the bacterial growth by $147 \mathrm{~mm}^{2}$.

The presence of FA in the conidia was also investigated. The fungus was grown in potato dextrose agar medium in petri plates for 10 days and the conidia were suspended in sterile distilled water. $150 \mathrm{ml}$ of the suspension (ca. 3,000 spores $/ \mathrm{ml}$ ) was incubated at room temperature for $24 \mathrm{~h}$, filtered off, the cell free filtrate was acidified and extracted thrice with equal volumes of ether. The solvent was flash evaporated and the residue was dissolved in $2 \mathrm{ml}$ methanol. When the extract was chromatographically analysed, a spot corresponding to the authentic FA was detected. The methanol extract possessed strong antibiotic activity; at $100 \mu \mathrm{l}$ the area of inhibition was $220 \mathrm{~mm}^{2}$ while at $300 \mu 1$ it was $575 \mathrm{~mm}^{2}$.

In conclusion, the wilt toxin fusaric acid was detected in the mycelium and conidia of Fusaritm oxysporum $\mathrm{f}$. vasinfectum.

Résumé. Le champignon Fusarium oxysporum f. vasinfectum contient de l'acide fusarique (l'acide 5-n-butyle picolinique) dans les filaments et spores.

\section{Chandramohan and A. Mahadevan}

Microbiology Laboratory, Faculty of Agriculture, Annamalai University, Annamalai Nagar (India), 13 December 1967.

1 E. Gäumann, Phytopathology 48,670 (1958).

a A. Mahadevan and D. Chandramohan, Med. Phytopath, in press (1967).

s E.STAHL, Thin Layer Chromatography, a laboratory handbook (Acadernic Press, New Yark 1965).

4.C. Smale and H.L. Kerl, Phytochemistry, 5,113 (1966). 